\title{
Heat stress and cow factors affect bacteria shedding pattern from naturally infected mammary gland quarters in dairy cattle
}

\author{
Johannes Hamel, ${ }^{1}$ ○ Yanchao Zhang, ${ }^{1} \odot$ Nicole Wente, ${ }^{1} \odot$ and Volker Krömker ${ }^{2 *}$ (]) \\ ${ }^{1}$ University of Applied Sciences and Arts Hannover, Faculty II, Department of Bioprocess Engineering - Microbiology, 30453 Hannover, Germany \\ ${ }^{2}$ University of Copenhagen, Faculty of Health and Medical Sciences, Department of Veterinary and Animal Sciences, Section Production, \\ Nutrition and Health, 1870 Frederiksberg C, Denmark
}

\section{ABSTRACT}

Mastitis-causing pathogens are shed from infected mammary gland quarters and thus contribute to an increased risk of new intramammary infections. The objective of the current study was to investigate the shedding characteristics of various mastitis-causing pathogens and associated animal-specific (somatic cell score and parity) and environmental (heat stress) factors. In a longitudinal study, infected udder quarters were sampled consecutively on 5 dairy farms in Germany. To capture climatic factors, temperaturehumidity index (THI) was calculated. In the laboratory analysis, the pathogens and their counts in the milk samples were determined. A generalized linear mixed model with gamma link was used to evaluate the factors influencing pathogen-shedding characteristics. The variables somatic cell count, pathogen, parity, and THI had significant influence on pathogen shedding. Staphylococci were shed in lower values than streptococci. The pathogen shedding from mammary gland quarters with intramammary infections was higher in the first and second lactation than in higher lactations. Exceeding the THI threshold 60 resulted in higher pathogen counts on the same day. This was only caused by the pathogens yeasts and Streptococcus uberis. Possible mechanisms causing differences in pathogen shedding are changes in the counts due to influenced milk quantities, better growth conditions at higher temperatures, or altered immunological reactions. The mechanisms often remain speculative and require further investigation. The study underlines the contribution of cows with high somatic cell counts regarding the transmission of mastitis pathogens within a herd. Furthermore, it becomes clear that heat stress in Germany influences udder health and that prevention measures are useful.

Received June 13, 2020.

Accepted August 26, 2020.

*Corresponding author: Volker.Kroemker@sund.ku.dk
Key words: intramammary infection, bacteria shedding, somatic cell count, heat stress

\section{INTRODUCTION}

Intramammary infections are one of the main causes of economic loss in dairy farming (Heikkilä et al., 2018). The causative udder pathogens are predominantly staphylococci, streptococci, and coliform species (Ruegg, 2017). There are pathogen-specific characteristics associated with the bacterial counts in milk. Compared with other common mastitis-causing pathogens, Staphylococcus aureus is shed at relatively low counts (Sears et al., 1990; Schukken et al., 2011; Walker et al., 2011). Higher shedding intensities are described for streptococci, such as Streptococcus uberis (Tassi et al., 2013) or Streptococcus dysgalactiae (Maye et al., 2017). Escherichia coli is also shed in high bacterial counts from infected mammary quarters (Schukken et al., 2011). In addition to the species-specific shedding intensity, strain-specific properties are known, for example, for Strep. uberis (Tassi et al., 2013). However, there are no studies that compare the shedding intensity of mastitiscausing pathogens from naturally occurring IMI. The shedding characteristics of bacteria from infected mammary quarters are not only determined by the pathogens and their characteristics. Hosts factors such as innate immune resistance, energy balance, immune status, parity, or stage of lactation can also be crucial for the severity and outcome of IMI (Keane, 2019). Basically, an increasing number of lactations is detrimental for the udder health, which is reflected in higher SCC (Hagnestam-Nielsen et al., 2009), a higher risk of IMI (Hertl et al., 2011), or lower bacteriological cure rates (Deluyker et al., 2005). Observations of dairy farmers support the hypothesis that changes in the husbandry environment affect the udder health and the occurrence of clinical mastitis. Kehrli et al. (2009) postulated that factors such as nutritional deficits and toxicities, as well as animal transport and commingling or the influence of drugs such as glucocorticoids, can lead to poorer 
udder health in dairy cows. It has previously been observed that the detection rate of Staph. aureus-infected udder quarters can be improved by sampling after stress-causing events such as claw trimming because of a higher bacteria shedding intensity (Krömker et al., 2008). Another possible environmental stress-causing factor on bacteria shedding is the climate or the change in weather conditions. A considerable number of studies have been published on the effect of heat stress on dairy cows. It is described that there is a negative influence of increasing temperature-humidity index (THI) on DMI and milk yield (West et al., 2003; Gorniak et al., 2014). Also, the SCC increases at higher THI levels (Nasr and El-Tarabany, 2017). Heat stress therefore seems to have an influence on udder health and probably also on the shedding intensity of mastitis-causing pathogens. However, there are no studies on the influence of the aforementioned environmental factors on the speciesspecific shedding intensity. In a study conducted by Deluyker et al. (2005), it was shown that the cure rate of subclinical mastitis (SCM) was higher for lower numbers of colonies in the pretreatment culture. In a study by Ziesch and Krömker (2016), the probability of bacteriological cure for clinical mastitis cases with a low shedding intensity of pathogens before treatment was also significantly $(P=0.01)$ higher than for cases with a high shedding rate (odds ratio $=2.535$ ). Bacteriashedding udder quarters are of practical relevance as they are an important source of infection for other cows in the herd (White et al., 2006; Barlow et al., 2009). A greater understanding of the shedding characteristics of mastitis-causing pathogens and the influencing factors thereof could contribute to improving the udder health in dairy farming.

The aims of the present study were (1) to investigate the shedding intensity of various mastitis-causing pathogens from mammary quarters with naturally occurring cases of IMI and (2) to evaluate the influence of associated factors under farm conditions in Germany.

\section{MATERIALS AND METHODS}

\section{Herds and Sample Collection}

During the period from May to November 2018, a longitudinal study was conducted in 5 conventional dairy herds (convenience sample) in northwestern Germany (Table 1). Selection criteria for the study were participation in the monthly German DHI program, the occurrence of SCM, a proper milking system for manual milk sampling (no automatic milking system), and a high level of cooperation from the employees. Based on the latest DHI report, cows with $\mathrm{SCC} \geq 200,000$ cells $/ \mathrm{mL}$ were selected for individual quarter foremilk sampling as this value is an internationally used threshold for detecting SCM in cows (Schepers et al., 1997). Animals with clinical mastitis or chronic IMI $(\geq 700,000$ cells/ $\mathrm{mL}$; Østerås, 2006) in the previous 3 mo were deliberately not included in the study. After foremilking and cleaning by the milker, mammary quarter milk samples were collected twice weekly (modal period between samplings: $3 \mathrm{~d}$ ) by the same investigator before milking. Mammary quarters with $\mathrm{SCC} \geq 200,000$ cells/mL or culture positive results in the first 3 sampling dates were included in the study until the end of the collection period (at least 4 and up to 17 times per herd). In the herds III and IV, unexpectedly few pathogen-shedding udder quarters were found. Therefore, the periods were kept short and sampling was continued on other farms. Milk samples were collected before evening milking (exception herd I: morning milking) in $10-\mathrm{mL}$ sterile plastic vials (containing boric acid, Ly20), following procedures recommended by the German Veterinary Association (DVG, 2018). For microbiological examination, samples were transported under cooled conditions to the laboratory of the University of Applied Sciences and Arts (Hannover, Germany). The sampling periods on the farms were carried out one after the other. A total of 5,736 milk samples from 180 cows were collected. Cows of all parities (1-7) and lactation stages were included in the study. To investigate the influence of parity in statistical analysis, cows were divided into 2 lactation groups (LGR): LGR1 (first and second lactation) and LGR2 (>second lactation).

\section{Laboratory Analysis}

Cultivation of the quarter milk samples and bacterial identification were carried out in accordance with the guidelines of the German Veterinary Association (DVG, 2018). Ten microliters of each milk sample were mixed with $90 \mu \mathrm{L}$ of Ringer's solution (Merck KGaA, Darmstadt, Germany) and plated on one separate esculin blood agar plate (Oxoid Deutschland GmbH, Wesel, Germany). The agar plates were incubated aerobically at $37^{\circ} \mathrm{C}$ and evaluated after 24 and $48 \mathrm{~h}$. In the presence of at least 1 colony, the samples were considered culture positive. If more than 2 pathogens were present, the sample was classified as contaminated. In pure and mixed cultures (maximum 2 different pathogens), the number of colonies was counted from 1 up to 300 (area of detection: 100-30,000 cfu/mL), and the pathogens were differentiated on the basis of the DVG (2018) guidelines. Additionally, a clumping factor test (DiaMondiaL, Staph Kit, Virotech Diagnostics GmbH, Vienna, Austria) was performed to differentiate Staph. aureus from NAS. To distinguish the Lancefield grouping of esculin-negative streptococci, a 
Table 1. Herds and sampling characteristics of 5 German dairy farms involved in a longitudinal field study on the shedding intensity of mastitis-causing pathogens

\begin{tabular}{|c|c|c|c|c|c|}
\hline \multirow[b]{2}{*}{ Item } & \multicolumn{5}{|c|}{ Herd } \\
\hline & I & II & III & IV & $\mathrm{V}$ \\
\hline Number of cows & 48 & 125 & 238 & 140 & 376 \\
\hline Sampled cows (no.) & 29 & 51 & 26 & 20 & 54 \\
\hline Sampled cows $(\%)$ & 60 & 41 & 11 & 14 & 14 \\
\hline Average milk yield (kg/d) DHI & 30.7 & 30.8 & 31.3 & 25.6 & 27.7 \\
\hline Average SCC $\left(\times 10^{3}\right.$ cells $\left./ \mathrm{mL}\right) \mathrm{DHI}$ & 454 & 253 & 316 & 197 & 218 \\
\hline Milking system & Herringbone & Herringbone & Herringbone & Rotary & Rotary \\
\hline Times visited & 12 & 17 & 6 & 4 & 14 \\
\hline Duration in weeks & 6 & 9 & 3 & 2 & 8 \\
\hline Number of milk samples & 585 & 2,128 & 604 & 316 & 2,103 \\
\hline
\end{tabular}

streptococcal grouping latex kit (DiaMondiaL, Strep Kit, Virotech Diagnostics GmbH) was used. Milk SCC was determined by flow cytometry (SomaScope Smart, Delta Instruments, B.V., Drachten, the Netherlands), and for statistical analysis transformed to the SCS using the formula:

$$
\mathrm{SCS}=\log _{2}(\mathrm{SCC} / 100,000)+3 .
$$

\section{Meteorological Data}

Meteorological data were obtained from the Deutscher Wetterdienst (German Meteorological Service, Offenbach am Main, Germany). The measurements were made at 3 different weather stations with an average distance to the farm of $11 \mathrm{~km}$ (maximum distance $14 \mathrm{~km})$. Mean hourly records of temperature $\left({ }^{\circ} \mathrm{C}\right)$ and relative humidity (\%) were used to calculate hourly THI in Microsoft Excel 2010 (Microsoft Corp., Redmond, WA) based on the following equation (Bohmanova et al., 2007):

$$
\begin{aligned}
\mathrm{THI}=(1.8 \times & \mathrm{T}+32)-(0.55-0.0055 \times \mathrm{RH}) \\
& \times(1.8 \times \mathrm{T}-26),
\end{aligned}
$$

where $\mathrm{T}$ is the mean ambient temperature $\left({ }^{\circ} \mathrm{C}\right)$ and $\mathrm{RH}$ is the mean relative humidity (\%). For statistical analysis, the THI was calculated for the current day as well as 1 and $2 \mathrm{~d}$ earlier, as studies showed the influence of the previous weather (West et al., 2003). The applied THI formula is appropriate for temperate climate zones (Bohmanova et al., 2007) and has already been used by other authors in Germany (Brügemann et al., 2012). Brügemann et al. (2012) considered a THI of 60 units as a general threshold for the upper point of thermoneutral zone for dairy cows in the German temperate climate. It was therefore calculated for each sampling day and up to 2 previous days whether the mean THI was $\leq 60$ or $>60$ (encoded as 0 or 1 , respectively). This variable is referred to as THI $60 \mathrm{~d}-\mathrm{x}$, where $\mathrm{x}$ is the time interval in days.

\section{Statistical Analysis}

The collection and processing of data were carried out with Microsoft Excel 2010 (Microsoft Corp.) and statistical analysis with SPSS 26.0 (IBM SPSS 25.0.0.0., IBM Inc., Armonk, NY). Pathogen-shedding udder quarters were each considered as subject. The mastitis pathogens studied were Staph. aureus, NAS, yeasts, Strep. uberis, and Strep. dysgalactiae. In cases of mixed infections (2 pathogens in one udder quarter), the respective udder quarter was considered as 2 subjects, one for each pathogen. To approximate the normal distribution, a logarithmic transformation $\left(\log _{10}\right)$ of the bacterial numbers was performed. The shedding intensity (in $\log _{10} \mathrm{cfu} / \mathrm{mL}$ ) was regarded as a dependent variable in all calculations. For the risk factor analyses, a generalized linear mixed model with a gamma link was used. The model allowed for gaps in the bacterial contents of consecutive milk samples, as nonevaluable samples may occur (e.g., due to contamination), or the bacteria concentrations may be below the detection level. Preliminary univariable analyses were done to select explanatory variables for the final analysis. Variables with $P \leq 0.1$ were retained for inclusion in the multivariable model. Farm, cow within farm and udder quarter in a cow were included as (nested) random effects. Factors thought to affect the bacterial counts in milk, such as the pathogen (PATH), SCS, LGR, THI $60 \mathrm{~d}-\mathrm{x}$, and maximum temperature, as well as numerous combinations of these, were tested. The multivariable analysis was performed using a backward stepwise selection and elimination procedure. After each run, the variable with the highest $P$-value was excluded from the model until all variables had $P \leq$ 0.05. The most optimal model was evaluated using the Akaike information criterion (AIC), where an AIC 
Table 2. Final generalized linear mixed model with variables significantly affecting pathogen shedding intensity from udder quarters with intramammary infections

\begin{tabular}{|c|c|c|c|c|c|c|}
\hline \multirow[b]{2}{*}{ Variable $^{1}$} & \multirow[b]{2}{*}{ Coefficient } & \multirow[b]{2}{*}{$\mathrm{SE}$} & \multirow[b]{2}{*}{ T-statistics } & \multirow[b]{2}{*}{$P$-value } & \multicolumn{2}{|c|}{$95 \%$ CI } \\
\hline & & & & & Lower limit & Upper limit \\
\hline \multicolumn{7}{|l|}{ Pathogen } \\
\hline Streptococcus dysgalactiae & -0.020 & 0.033 & -0.620 & 0.536 & -0.084 & 0.044 \\
\hline Yeasts & -0.048 & 0.024 & -2.036 & 0.042 & -0.094 & -0.002 \\
\hline NAS & -0.165 & 0.013 & -12.496 & 0.001 & -0.191 & -0.139 \\
\hline LGR1 & 0.041 & 0.012 & 3.414 & 0.001 & 0.017 & 0.064 \\
\hline LGR2 & $0^{2}$ & & & & & \\
\hline \multicolumn{7}{|l|}{ THI threshold d 0} \\
\hline $\mathrm{THI} \leq 60$ & -0.073 & 0.023 & -3.117 & 0.002 & -0.119 & -0.027 \\
\hline THI $>60$ & $0^{2}$ & & & & & \\
\hline
\end{tabular}

${ }^{1} \mathrm{LGR} 1=$ first and second lactation, LGR 2 = third and higher lactations, THI = temperature-humidity index.

${ }^{2}$ This coefficient is set at 0 because it is redundant.

with the lowest value indicated the best model. Confounding was monitored by the change in the coefficient of a variable after removing another variable from the model. If the change of the estimates exceeded $25 \%$, the removed variable was considered a potential confounder and was included again in the model. In the final model, all biologically plausible 2 -way interactions were tested. Model fit was evaluated by checking normality of the residuals. The random effects were kept as design variables even though they were not significant in the models. Least squares means from the model were calculated. A $P$-value $<0.05$ was considered indicative of a statistically significant difference.

\section{RESULTS}

The total number of measured values of bacteria (and yeasts) from shedding udder quarters included in the analysis was 2,133 (Strep. dysgalactiae, $\mathrm{n}=73$; yeasts, $\mathrm{n}=89$; Staph. aureus, $\mathrm{n}=201$; Strep. uberis, $\mathrm{n}=311 ;$ NAS, $\mathrm{n}=1,459$ ), shed from 703 subjects (an udder quarter, which sheds a pathogen several times). The maximum number of measurements per subject was 16 . In the generalized mixed model, the following factors were found to have a significant $(P<0.01)$ influence on the target variable: SCS, PATH, LGR, THI threshold $60 \mathrm{~d} 0$ (Table 2) and their interactions. The examined staphylococci (Staph. aureus and NAS) were shed at relatively low concentrations (3.41 vs. $3.55 \log _{10}$ $\mathrm{cfu} / \mathrm{mL})$, but with significant $(P<0.01)$ differences between them (Table 3). Yeasts were shed at the same counts $\left(3.62 \log _{10} \mathrm{cfu} / \mathrm{mL}\right)$ as NAS. Significantly $(P$ $<0.01$ ) highest were the counts of Strep. uberis and Strep. dysgalactiae (4.03 vs. $4.04 \log _{10} \mathrm{cfu} / \mathrm{mL}$ ), which did not differ between the 2 species. The mean shed- ding intensity of the considered pathogens was higher in the first and second lactation than in higher lactations (3.80 vs. $3.65 \log _{10} \mathrm{cfu} / \mathrm{mL}$ ). Exceeding the THI threshold 60 led to an increase in pathogen shedding on the same day. Figure 1 presents the influence of THI on the individual species shedding. Yeasts and Strep. uberis were shed at higher counts when the THI threshold 60 was exceeded.

\section{DISCUSSION}

In the present study, the shedding intensity of 5 mastitis-causing pathogens from mammary quarters with IMI and the influence of associated factors were investigated under farm herd conditions in Germany. To evaluate this over time, the longitudinal study design was chosen and individual udder quarters were sampled twice a week at relatively short intervals (modal: 3 d). After the described selection of udder quarters at the beginning of the sampling period, only few udder quarters were eliminated. Thus, the panel mortality had almost no relevance in this longitudinal study. It is critical to note that pathogens with a relatively short duration of infection, such as E. coli (Schukken et al., 2011), could not be adequately depicted and were therefore not included in the present study. The SCS was positively associated with the shedding intensity of the mastitis-causing pathogens being studied. This indicates that cows with a high SCC endanger the udder health of a herd (White et al., 2006; Barlow et al., 2009), as it can be assumed that a higher shedding intensity also increases the risk of infections of other cows. The shedding intensity differed between the pathogens. The lowest counts of bacteria in milk were found for Staph. aureus compared with the other stud- 
Table 3. Least squares means of the log-transformed bacterial shedding depending on the pathogen, the parity and the THI threshold 60 of the same day

\begin{tabular}{|c|c|c|c|c|}
\hline \multirow[b]{2}{*}{ Variable } & \multirow{2}{*}{$\begin{array}{c}\log _{10} \\
\mathrm{cfu} / \mathrm{mL}\end{array}$} & \multirow[b]{2}{*}{$\mathrm{SE}$} & \multicolumn{2}{|c|}{$95 \% \mathrm{CI}$} \\
\hline & & & Lower limit & Upper limit \\
\hline \multicolumn{5}{|l|}{ Pathogen } \\
\hline Staphylococcus aureus & $3.41^{\mathrm{a}}$ & 0.11 & 3.20 & 3.63 \\
\hline NAS & $3.55^{\mathrm{bc}}$ & 0.11 & 3.35 & 3.77 \\
\hline Yeasts & $3.62^{\mathrm{c}}$ & 0.13 & 3.37 & 3.90 \\
\hline Streptococcus uberis & $4.03^{\mathrm{d}}$ & 0.13 & 3.78 & 4.30 \\
\hline Streptococcus dysgalactiae & $4.04^{\mathrm{d}}$ & 0.15 & 3.76 & 4.34 \\
\hline \multicolumn{5}{|l|}{ Paritiy $^{1,2}$} \\
\hline LGR1 & $3.80^{\mathrm{a}}$ & 0.12 & 3.57 & 4.05 \\
\hline LGR2 & $3.65^{\mathrm{b}}$ & 0.11 & 3.44 & 3.87 \\
\hline \multicolumn{5}{|l|}{ THI threshold d $0^{2}$} \\
\hline $\mathrm{THI} \leq 60$ & $3.61^{\mathrm{a}}$ & 0.12 & 3.39 & 3.85 \\
\hline THI $>60$ & $3.84^{\mathrm{b}}$ & 0.12 & 3.61 & 4.08 \\
\hline
\end{tabular}

${ }^{\mathrm{a}-\mathrm{d}}$ Means within a category with different superscripts differ $(P<0.05)$.

${ }^{1}$ LGR $1=$ first and second lactation; LGR2 $=$ third and higher lactations.

${ }^{2}$ The values for parity and temperature-humidity index (THI) threshold d 0 contain all pathogens.

ied pathogens. In a frequently cited study of Sears et al. (1990), a differentiation was made between low and high shedders. Experimentally infected udder quarters with a mean of $<1,000 \mathrm{cfu} / \mathrm{mL}$ were considered to be low shedders, and those with a mean of $\geq 2,000 \mathrm{cfu} /$ $\mathrm{mL}$ as high shedders (corresponding to 3.0 and $3.3 \log _{10}$ $\mathrm{cfu} / \mathrm{mL}$, respectively). The Staph. aureus infections of the current study would thus be categorized as high shedders. It should be noted that these are natural and not experimental infections, and that no clinical signs were found. Walker et al. (2011) found a mean shedding of $242.9 \mathrm{cfu} / 0.01 \mathrm{~mL}$ (corresponding to $4.4 \log _{10}$ $\mathrm{cfu} / \mathrm{mL}$ ) from naturally infected udder quarters. In a study by Pellegrino et al. (2010), the shedding from experimentally infected udder quarters was $4.1 \log _{10}$ cfu/mL. Investigations by Mørk et al. (2012) indicated that Staph. aureus infections with a bacterial shedding intensity of $\geq 500 \mathrm{cfu} / \mathrm{mL}$ (corresponding to $2.7 \log _{10}$

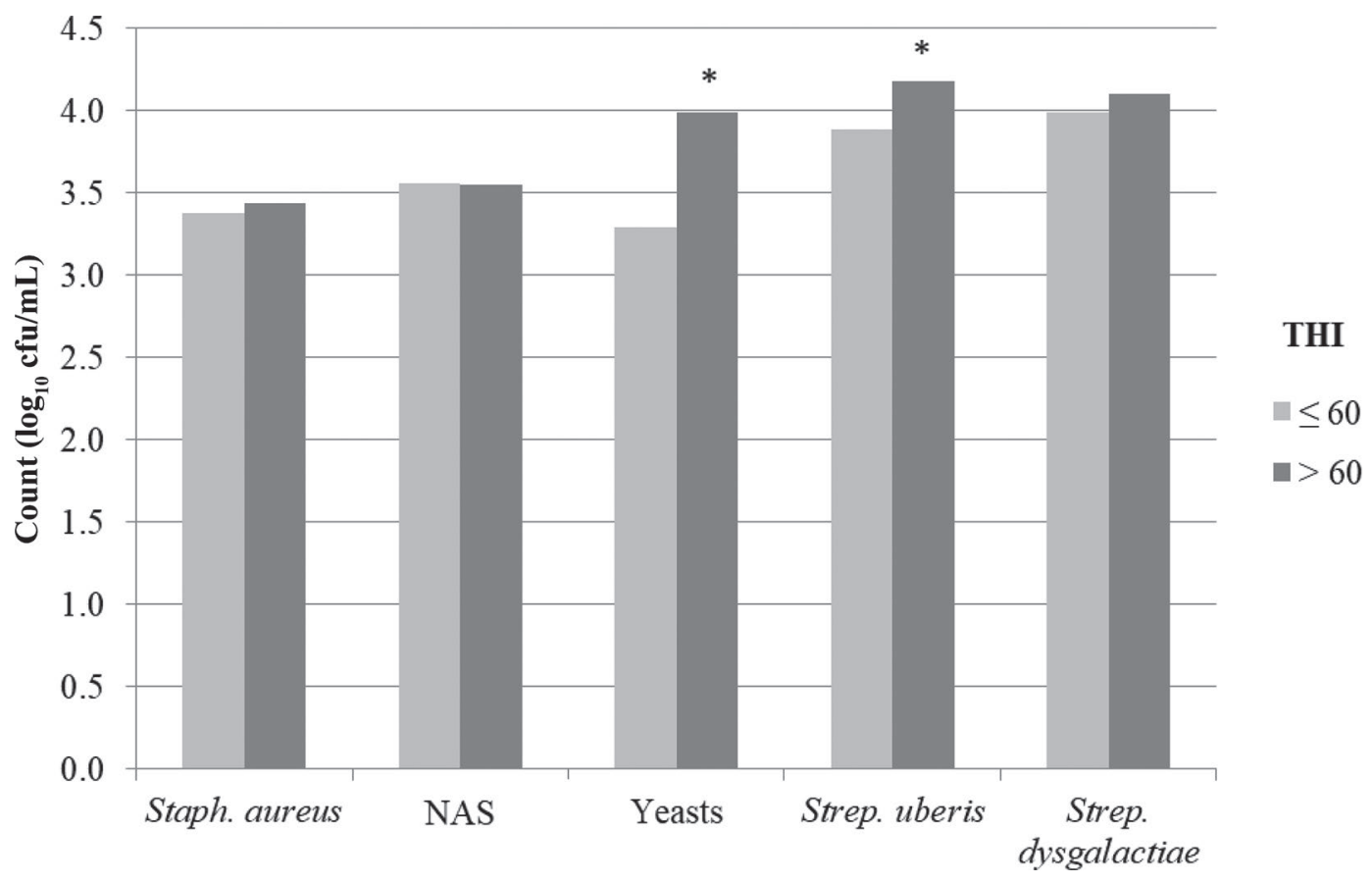

Figure 1. Pathogen shedding intensity from infected mammary gland quarters and the influence of temperature-humidity index (THI) threshold 60 of the same day. ${ }^{*}$ indicates significant difference $(P<0.05)$. 
$\mathrm{cfu} / \mathrm{mL}$ ) are more likely to persist than those with lower shedding intensities. The results overall confirm that Staph. aureus is shed at low levels. The NAS were shed at a significantly $(P<0.01)$ higher intensity than Staph. aureus in the present investigation. In a study by Wald et al. (2019), the median NAS shedding intensity in clinical and subclinical mastitis was in the range of 3 to $4 \log _{10} \mathrm{cfu} / \mathrm{mL}$. Although this corresponds in the broader sense to the NAS bacteria shedding estimated in our study $\left(3.55 \log _{10} \mathrm{cfu} / \mathrm{mL}\right)$, the range indicated is very wide. Furthermore, because NAS are an inhomogeneous group of staphylococci, it is no longer recommended to make statements about them as a group (De Visscher et al., 2015). Recent research has shown that there are differences in the shedding intensity of NAS species (Hamel et al., 2020). In the present study, yeasts were shed at the same level as NAS. In the laboratory analyses, mainly Candida species were found, which were not further differentiated. These are considered to be partly responsible for mastitis, but also occur as contaminants (Williamson and di Menna, 2007). There are no previous studies on the shedding intensity of the group of yeasts or individual species. Further research is therefore needed in this respect. Significantly $(P<0.01)$ higher shedding intensities were estimated for Strep. uberis and Strep. dysgalactiae. Streptococcus uberis has become a pathogen of growing interest in recent years and is considered to be environment associated. However, persistence in the udder tissue is still possible and a contagious pattern of transmission is also assumed (Krömker et al., 2014). Tassi et al. (2013) demonstrated strain-specific pathogenicity, which was also reflected in the shedding intensity. A putatively host-adapted Strep. uberis strain reached a bacterial concentration of $7.67 \log _{10} \mathrm{cfu} / \mathrm{mL} 36 \mathrm{~h}$ after the artificial infection. After $96 \mathrm{~h}$, the concentration decreased to $3.49 \log _{10} \mathrm{cfu} / \mathrm{mL}$ and remained at this level until the end of the study (312 h). In contrast, the unadapted strain under investigation only reached a maximum shedding intensity of $2.91 \log _{10} \mathrm{cfu} / \mathrm{mL}$ (24 h after challenge). In the present study, naturally occurring cases of IMI caused by Strep. uberis were investigated, and it was found that the average shedding intensity was $4.03 \log _{10} \mathrm{cfu} / \mathrm{mL}$. This can be compared with the host-adapted strain by Tassi et al. (2013). The shedding of Strep. dysgalactiae occurs in similar or even higher values. In a study conducted by Maye et al. (2017), bacterial counts peaked at 8.7 to $9.3 \log _{10} \mathrm{cfu} /$ $\mathrm{mL}$. It is critical to note that in the current study, the detection range at the upper limit only included bacteria concentrations up to $30,000 \mathrm{cfu} / \mathrm{mL}$ (corresponding to $4.48 \log _{10} \mathrm{cfu} / \mathrm{mL}$ ). About $52 \%$ of the values of Strep. dysgalactiae and $36 \%$ of Strep. uberis were at the upper limit. Therefore, higher detection limits should be used in further studies to investigate the shedding characteristics of streptococci. Finally, it does not change the central statement that streptococci are shed in higher concentrations than staphylococci, which is in agreement with the statement of Schukken et al. (2011). In further investigations into the shedding characteristics of streptococci, the detection range should be extended.

In the current study, the shedding intensity of mastitis-causing pathogens was higher in the first and second lactation compared with higher parities. This seems contradictory, as cows of higher parities tend to have poorer udder health, which is reflected, for example, in higher levels of somatic cells in milk (HagnestamNielsen et al., 2009). The risk of contracting an IMI and also the lactational incidence risk of second and third cases are higher in multiparous cows (Hertl et al., 2011). Furthermore, the bacteriological cure rate is lower in higher parities (Deluyker et al., 2005). Nevertheless, the question remains why cows in the current study in the first and second lactation shed the considered pathogens in higher concentrations than older cows. A possible justification could be the culling regimen of the herds under study. Hertl et al. (2011) showed that both primipara and multipara with clinical mastitis in the first 10 mo of lactation had a higher risk of being sold. Perhaps cows with mastitis in the higher lactations of the studied herds were more consistently culled than in the first 2 lactations. Another justification could be a dilution effect. The milk yield increases from lactation to lactation. Assuming that the reproductive intensity of the pathogen is independent of the host's parity, this could result in lower pathogen shedding intensities in older cows with higher milk yields. Furthermore, the immunological status of older cows could be relevant. The immune responses to mastitis pathogens are very species-specific and not fully understood. Petzl et al. (2018) assume that the induction of innate immune mechanisms in the udder by any (mastitis) pathogen leads to a better immune response (cross-protection). Herry et al. (2017) examined the effect of local immunization against $E$. coli and found an overall positive effect by limiting inflammation and accelerating bacterial clearance. In the current study, it can be assumed that multiparous cows had already had contact with mastitis-causing pathogens in previous lactations, which did not necessarily lead to elevated SCC or clinical signs, but stimulated the local immunological processes and finally led to the lower shedding intensities of pathogens from udder quarters with IMI at the time of our investigations. Indeed, causal factors leading to higher pathogen shedding from cows in first and second lactation remain speculative and require further research.

It has long been known that heat stress adversely affects dairy cows (Kadzere et al., 2002, West et al., 
2003, Nasr and El-Tarabany, 2017). In the temperate climate in Germany, cows are affected by heat stress in the warmest months of the year (Gorniak et al., 2014). The THI takes into account ambient temperature and relative humidity and is often used to investigate the effect of heat stress. The choice of the appropriate THI depends primarily on the climate zone (Bohmanova et al., 2007). The THI used in the current study is suitable for the humid climate. Brügemann et al. (2012) viewed the threshold value of THI $=60$ as the upper point of the thermoneutral zone for dairy cows in Germany. This threshold may appear low. It should be noted that the THI values with the formula applied in the temperate climate in Germany cannot be compared with those in hotter climates, which are often considerably higher. In the current study, significant $(P<0.01)$ effects on shedding intensity were found at this threshold value. The increased bacterial count in repeated detection of a pathogen from one udder quarter led to this result. It should be critically noted that the repeated detection of a pathogen could also be caused by a new infection with the same pathogen or with another strain of it (Wente et al., 2020). However, the sampling intervals in this longitudinal study were relatively short (modal: 3 d), which should minimize any adverse effects in this context. The difference in the shedding intensity when THI rises above 60 was finally only caused by the pathogens yeasts and Strep. uberis. Little is known about the direct influence of heat stress on mastitis and the mechanisms behind it. One reason for the higher shedding intensity of these mastitis-causing pathogens could be a concentration of the pathogens at lower milk yield due to heat stress. Despite the fact that the milk yield was not measured in the current study, it can be assumed that high THI led to a lower milk production as is frequently described (West et al., 2003, Gorniak et al., 2014, Zeinhom et al., 2016, Nasr and El-Tarabany, 2017). Assuming a constant growth rate of the pathogens, a concentration of the pathogens in milk could have been caused by a lower milk yield alone. However, what speaks against this assumption of concentration is that the THI of the previous days had no influence on the pathogen shedding. In a study by West et al. (2003), the THI $2 \mathrm{~d}$ earlier had the greatest effect on milk yield. Another reason for higher pathogen counts could be that the pathogens have better conditions for reproduction in the mammary gland, due to, for example, higher milk temperatures, which have been shown to be caused by high ambient temperatures (West et al., 2003). A further reason for the higher shedding intensity of pathogens at high THI could be an inadequate immune function. It is known that the mammary gland function is influenced by heat stress. The mechanisms behind this are manifold, with systemic reactions of the immune system as well as affected local immune functions in the mammary gland (Tao et al., 2018). Finally, the question arises why yeasts and Strep. uberis were shed at higher intensities when the THI threshold 60 was exceeded, but the other pathogens investigated were not. For Strep. dysgalactiae, it should again be noted that the shedding intensity was largely above the detection range. Consequently, the effect of the THI could therefore not be established and further investigations should be carried out. Staphylococcus aureus is regarded as a mastitis pathogen well adapted to the mammary gland, partly because it has developed means to evade immune system recognition (Schukken et al., 2011; Keane, 2019). The situation is probably similar for NAS, which show some similarities to Staph. aureus (Taponen and Pyorala, 2009). It is therefore possible that the THI had no influence on their shedding intensity in our investigations. Finally, this study confirms that udder health in the temperate German climate is influenced by heat stress. Consequently, preventive mitigating measures should be taken.

Seasonal effects on the incidence rate of clinical mastitis caused by different pathogens have been reported. For example, incidence rate of clinical mastitis for Strep. uberis was highest in summer (August, Northern Hemisphere), whereas other pathogens, such as Staph. aureus, E. coli, and Strep. dysgalactiae, more likely appear in winter (December and January; Olde Riekerink et al., 2007). However, the findings are not uniform. Zeinhom et al. (2016) reported a higher isolation rate for Staph. aureus and E. coli at high THI levels. It can be assumed that pathogen shedding influences the detection of certain mastitis pathogens. Thus, it is plausible that existing cases of IMI only become easier to detect through heat stress, as the pathogen shedding increases and is therefore easier to identify in the microbiological examination. Furthermore, it can be assumed that clinical mastitis may become more frequent due to the exacerbation of subclinical cases that progress to a clinical state.

Overall, stress appears to have a considerable effect on the shedding intensity of mastitis-causing pathogens, which was demonstrated in the present study for heat stress. Different theories exist in the literature regarding the mechanisms by which stress causes an inadequate immune response. Elvinger et al. (1992) observed a reduced migration of leukocytes to the mammary gland due to heat stress, as well as increased plasma cortisol concentrations. It has been demonstrated that the experimental injection of glucocorticoids (cortisol or dexamethasone) can increase the shedding intensity of Staph. aureus (Burton and Kehrli, 1995). It is therefore assumed that the host's response to a mastitis-causing pathogen is influenced by several stressors that lead 
to an increase in plasma cortisol concentration, which can influence the bacteria shedding intensity. Based on these stress mechanisms and the influence of THI shown in this study, we assume that stress events can exacerbate existing IMI. Further studies should investigate the influence of possible stress-causing events in the environment of dairy cows under more controlled conditions.

\section{CONCLUSIONS}

The shedding intensity of mastitis-causing pathogens differs. Staphylococci are shed at lower levels than streptococci. Higher pathogen counts occur with a higher somatic cell content, lower parity, and higher THI. This underlines that cows with high SCC are a source of mastitis pathogens in a herd. The higher shedding intensities in the first 2 lactations compared with higher parities could not be conclusively clarified. This study confirms that dairy cows in the German temperate climate are affected by heat stress and that this is also specifically detrimental to udder health. Even if the causes cannot be conclusively explained, it can be assumed that the prevention and mitigation of heat stress are beneficial to udder health.

\section{ACKNOWLEDGMENTS}

The authors thank the Steinbeis Research Center for Dairy Science (Kirchlengern, Germany) for supporting the study by funding the first author. The authors have not stated any conflicts of interest.

\section{REFERENCES}

Barlow, J. W., L. J. White, R. N. Zadoks, and Y. H. Schukken. 2009. A mathematical model demonstrating indirect and overall effects of lactation therapy targeting subclinical mastitis in dairy herds. Prev. Vet. Med. 90:31-42. https://doi.org/10.1016/j.prevetmed 2009.03 .016

Bohmanova, J., I. Misztal, and J. B. Cole. 2007. Temperature-humidity indices as indicators of milk production losses due to heat stress. J. Dairy Sci. 90:1947-1956. https://doi.org/10.3168/jds.2006-513.

Brügemann, K., E. Gernand, U. König von Borstel, and S. König. 2012. Defining and evaluating heat stress thresholds in different dairy cow production systems. Arch. Anim. Breed. 55:13-24. https://doi.org/10.5194/aab-55-13-2012.

Burton, J. L., and M. E. Kehrli. 1995. Regulation of neutrophil adhesion molecules and shedding of Staphylococcus aureus in milk of cortisol-treated and dexamethason-treated cows. Am. J. Vet. Res. 56:997-1006

De Visscher, A., S. Piepers, K. Supre, F. Haesebrouck, and S. De Vliegher. 2015. Short communication: Species group-specific predictors at the cow and quarter level for intramammary infection with coagulase-negative staphylococci in dairy cattle throughout lactation. J. Dairy Sci. 98:5448-5453. https://doi.org/10.3168/jds .2014-9088.

Deluyker, H. A., S. N. Van Oye, and J. F. Boucher. 2005. Factors affecting cure and somatic cell count after pirlimycin treatment of subclinical mastitis in lactating cows. J. Dairy Sci. 88:604-614. https://doi.org/10.3168/jds.S0022-0302(05)72724-7.

DVG. 2018. Leitlinien-Entnahme von Milchproben unter antiseptischen Bedingungen und Isolierung und Identifizierung von Mastitiserregern [Guidelines for Aseptic Milk Sampling and Guidelines to Isolate and Identify Mastitis Pathogens]. 3th ed. Deutsche Veterinärmedizinische Gesellschaft e.V. [German Veterinary Medical Society], Giessen, Germany.

Elvinger, F., R. P. Natzke, and P. J. Hansen. 1992. Interactions of heat stress and bovine somatotropin affecting physiology and immunology of lactating cows. J. Dairy Sci. 75:449-462. https://doi.org/10 .3168/jds.S0022-0302(92)77781-9.

Gorniak, T., U. Meyer, K.-H. Südekum, and S. Dänicke. 2014. Impact of mild heat stress on dry matter intake, milk yield and milk composition in mid-lactation Holstein dairy cows in a temperate climate. Arch. Anim. Nutr. 68:358-369. https://doi.org/10.1080/ 1745039X.2014.950451.

Hagnestam-Nielsen, C., U. Emanuelson, B. Berglund, and E. Strandberg. 2009. Relationship between somatic cell count and milk yield in different stages of lactation. J. Dairy Sci. 92:3124-3133. https:/ /doi.org/10.3168/jds.2008-1719.

Hamel, J., Y. Zhang, N. Wente, and V. Krömker. 2020. Non-S. aureus staphylococci (NAS) in milk samples: Infection or contamination? Vet. Microbiol. 242:108594. https://doi.org/10.1016/j.vetmic.2020 .108594.

Heikkilä, A. M., E. Liski, S. Pyörälä, and S. Taponen. 2018. Pathogen-specific production losses in bovine mastitis. J. Dairy Sci. 101:9493-9504. https://doi.org/10.3168/jds.2018-14824.

Herry, V., C. Gitton, G. Tabouret, M. Répérant, L. Forge, C. Tasca, F. B. Gilbert, E. Guitton, C. Barc, C. Staub, D. G. E. Smith, P. Germon, G. Foucras, and P. Rainard. 2017. Local immunization impacts the response of dairy cows to Escherichia coli mastitis. Sci. Rep. 7:3441. https://doi.org/10.1038/s41598-017-03724-7.

Hertl, J. A., Y. H. Schukken, D. Bar, G. J. Bennett, R. N. González, B. J. Rauch, F. L. Welcome, L. W. Tauer, and Y. T. Grohn. 2011. The effect of recurrent episodes of clinical mastitis caused by gram-positive and gram-negative bacteria and other organisms on mortality and culling in Holstein dairy cows. J. Dairy Sci. 94:48634877. https://doi.org/10.3168/jds.2010-4000.

Kadzere, C. T., M. R. Murphy, N. Silanikove, and E. Maltz. 2002. Heat stress in lactating dairy cows: A review. Livest. Prod. Sci. 77:59-91. https://doi.org/10.1016/S0301-6226(01)00330-X.

Keane, O. M. 2019. Symposium review: Intramammary infectionsMajor pathogens and strain-associated complexity. J. Dairy Sci. 102:4713-4726. https://doi.org/10.3168/jds.2018-15326.

Kehrli, M. E., J. F. Ridpath, and J. D. Neill. 2009. Immune suppression in cattle: Contributors and consequences. Pages 103-112 in Proc. National Mastitis Council 48rd Annual Meeting. NMC, Naperville, IL.

Krömker, V., J. Friedrich, and D. Klocke. 2008. Shedding patterns of $S$. aureus in quarter foremilk samples of cows with known $S$. aureus infections. Tierärztl. Prax. Ausg. G. 36:389-392.

Krömker, V., F. Reinecke, J. H. Paduch, and N. Grabowski. 2014. Bovine Streptococcus uberis intramammary infections and mastitis. Clin. Microbiol. 3:157. https://doi.org/10.4172/2327-5073 .1000157 .

Maye, S., J. Flynn, C. Stanton, G. F. Fitzgerald, and P. M. Kelly. 2017. Bovine intra-mammary challenge with Streptococcus dysgalactiae spp. dysgalactiae to explore the effect on the response of complement activity. J. Dairy Res. 84:293-299. https://doi.org/10 .1017/S0022029917000292.

Mørk, T., H. J. Jørgensen, M. Sunde, B. Kvitle, S. Sviland, S. Waage, and T. Tollersrud. 2012. Persistence of staphylococcal species and genotypes in the bovine udder. Vet. Microbiol. 159:171-180. https: //doi.org/10.1016/j.vetmic.2012.03.034.

Nasr, M. A. F., and M. S. El-Tarabany. 2017. Impact of three THI levels on somatic cell count, milk yield and composition of multiparous Holstein cows in a subtropical region. J. Therm. Biol. 64:73-77. https://doi.org/10.1016/j.jtherbio.2017.01.004.

Olde Riekerink, R. G. M., H. W. Barkema, and H. Stryhn. 2007. The effect of season on somatic cell count and the incidence of clinical 
mastitis. J. Dairy Sci. 90:1704-1715. https://doi.org/10.3168/jds .2006-567.

Østerås, O. 2006. Mastitis epidemiology-Practical approaches and applications. Pages 203-215 in Proc. 24. World Buiatrics Congress, Nice, France.

Pellegrino, M., J. Giraudo, C. Raspanti, L. Odierno, and C. Bogni. 2010. Efficacy of immunization against bovine mastitis using a Staphylococcus aureus avirulent mutant vaccine. Vaccine 28:45234528. https://doi.org/10.1016/j.vaccine.2010.04.056.

Petzl, W., H. Zerbe, J. Günther, H. M. Seyfert, J. Hussen, and H. J. Schuberth. 2018. Pathogen-specific responses in the bovine udder. Models and immunoprophylactic concepts. Res. Vet. Sci. 116:5561. https://doi.org/10.1016/j.rvsc.2017.12.012.

Ruegg, P. L. 2017. A 100-Year Review: Mastitis detection, management, and prevention. J. Dairy Sci. 100:10381-10397. https://doi .org/10.3168/jds.2017-13023.

Schepers, A. J., T. Lam, Y. H. Schukken, J. B. M. Wilmink, and W. J. A. Hanekamp. 1997. Estimation of variance components for somatic cell counts to determine thresholds for uninfected quarters. J. Dairy Sci. 80:1833-1840. https://doi.org/10.3168/jds.S0022 -0302(97)76118-6.

Schukken, Y. H., J. Günther, J. Fitzpatrick, M. C. Fontaine, L. Goetze, O. Holst, J. Leigh, W. Petzl, H. J. Schuberth, A. Sipka, D. G. E. Smith, R. Quesnell, J. Watts, R. Yancey, H. Zerbe, A. Gurjar, R. N. Zadoks, and H. M. Seyfert. 2011. Host-response patterns of intramammary infections in dairy cows. Vet. Immunol. Immunopathol. 144:270-289. https://doi.org/10.1016/j.vetimm.2011.08 .022 .

Sears, P. M., B. S. Smith, P. B. English, P. S. Herer, and R. N. Gonzalez. 1990. Shedding pattern of Staphylococcus aureus from bovine intramammary infections. J. Dairy Sci. 73:2785-2789. https://doi .org/10.3168/jds.S0022-0302(90)78964-3.

Tao, S., R. M. Orellana, X. Weng, T. N. Marins, G. E. Dahl, and J. K. Bernard. 2018. Symposium review: The influences of heat stress on bovine mammary gland function. J. Dairy Sci. 101:5642-5654. https://doi.org/10.3168/jds.2017-13727.

Taponen, S., and S. Pyörälä. 2009. Coagulase-negative staphylococci as cause of bovine mastitis - Not so different from Staphylococcus aureus? Vet. Microbiol. 134:29-36. https://doi.org/10.1016/j .vetmic.2008.09.011.

Tassi, R., T. N. McNeilly, J. L. Fitzpatrick, M. C. Fontaine, D. Reddick, C. Ramage, M. Lutton, Y. H. Schukken, and R. N. Zadoks. 2013. Strain-specific pathogenicity of putative host-adapted and nonadapted strains of Streptococcus uberis in dairy cattle. J. Dairy Sci. 96:5129-5145. https://doi.org/10.3168/jds.2013-6741.

Wald, R., C. Hess, V. Urbantke, T. Wittek, and M. Baumgartner. 2019. Characterization of Staphylococcus species isolated from bovine quarter milk samples. Animals (Basel) 9:200. https://doi.org/ 10.3390/ani9050200.

Walker, J. B., P. J. Rajala-Schultz, W. L. Walker, J. L. Mathews, W. A. Gebreyes, and F. J. DeGraves. 2011. Variation in daily shedding patterns of Staphylococcus aureus in naturally occurring intramammary infections. J. Vet. Diagn. Invest. 23:1114-1122. https:// doi.org/10.1177/1040638711425587.

Wente, N., A. S. Grieger, D. Klocke, J. H. Paduch, Y. Zhang, S. Leimbach, M. Tho Seeth, E. M. Mansion-De Vries, E. Mohr, and V. Krömker. 2020. Recurrent mastitis-Persistent or new infections? Vet. Microbiol. 244:108682. https://doi.org/10.1016/j.vetmic.2020 .108682 .

West, J. W., B. G. Mullinix, and J. K. Bernard. 2003. Effects of hot, humid weather on milk temperature, dry matter intake, and milk yield of lactating dairy cows. J. Dairy Sci. 86:232-242. https://doi .org/10.3168/jds.S0022-0302(03)73602-9.

White, L. J., T. J. G. M. Lam, Y. H. Schukken, L. E. Green, G. F. Medley, and M. J. Chappell. 2006. The transmission and control of mastitis in dairy cows: A theoretical approach. Prev. Vet. Med. 74:67-83. https://doi.org/10.1016/j.prevetmed.2006.01.008.

Williamson, J. H., and M. E. di Menna. 2007. Fungi isolated from bovine udders, and their possible sources. N. Z. Vet. J. 55:188-190. https://doi.org/10.1080/00480169.2007.36766.

Zeinhom, M. M. A., R. L. Abdel Aziz, A. N. Mohammed, and U. Bernabucci. 2016. Impact of seasonal conditions on quality and pathogens content of milk in Friesian cows. Asian-Australas. J. Anim. Sci. 29:1207-1213. https://doi.org/10.5713/ajas.16.0143.

Ziesch, M., and V. Krömker. 2016. Factors influencing bacteriological cure after antibiotic therapy of clinical mastitis. Milchwissenschaft 69:7-14.

\section{ORCIDS}

Johannes Hamel ๑ https://orcid.org/0000-0002-1684-0288 Yanchao Zhang (ㅇ https://orcid.org/0000-0002-4028-9326

Nicole Wente ๑ https://orcid.org/0000-0001-7513-9478

Volker Krömker @ https://orcid.org/0000-0002-5678-2502 